\title{
Pengembangan Bahan Ajar pada Mata Kuliah Belajar dan Pembelajaran di Fakultas Keguruan dan Ilmu Pendidikan Universitas Batanghari Jambi
}

\author{
Buyung ${ }^{1}$ \\ Dosen FKIP Universitas Batanghari Jambi ${ }^{l}$ \\ Email : buyungplaho@ymail.com, buyungplaho@gmail.com
}

\begin{abstract}
This study aims to develop learning and learning teaching materials. The research method used is rehabilitation and development $(R \& D)$. The development model of teaching materials used is the Dick and Carey model. This research was carried out in the Faculty of Teacher Training and Education in even semester 2017/2018. Data collection using questionnaires, interviews and observations. The results based on validation by experts were categorized as feasible with the feasibility percentage for design validation $93.33 \%$, media validation $93.33 \%$ and $95.4 \%$ material experts. Followed by a one to one response trial there are words that are difficult to understand and use and have been corrected according to students' understanding. In the small group trial the response was good and there was no improvement. Then in the Field Trial trial (field group) received a response that the implementation of learning was smooth and enjoyable, with teaching materials that were easy to understand and in accordance with the needs of the user. From the results of Validation and trials conducted, it can be concluded that teaching and learning teaching materials are suitable for use.
\end{abstract}

Keywords: teaching materials, learning and learning, Dick and Carey models

\section{PENDAHULUAN}

Perubahan dalam sistem pendidikan menjadi tuntutan suatu bangsa untuk memiliki sumber daya manusia yang berkualitas. Sumber daya manusia yang siap menghadapi segala situasi dan kondisi dalam menghadapi perkembangan zaman, termasuk konsep pendidikan. Perubahan konsep pendidikan akan berpengaruh terhadap cara dan sistem penyampaian pendidikan di perguruan tinggi.

Penyampaikan pendidikan di perguruan tinggi di dasarkan pada kurikulum yang sudah disusun oleh pernguruan tinggi masing-masing karena merupakan hak perguruan tinggi. Hal tersebut menyebabkan perubahan dalam pembelajaran di yang dilakukan oleh para dosen yang ada di perguruan tinggi harus sesuai dengan tuntutan zaman. Perubahan ilmu pengetahuan harus di kaji secara seksama sehingga ilmu pengetahuan yang akan didapat oleh mahasiswa harus sesuai dangan perubahan yang ada pada terjadi saat itu. Keadaan seperti ini menuntut para dosen harus melakukan inovasi pada segi ilmu pengetahuan yang akan dipelajari oleh mahasiswa.

Mahasiswa sebagai cara guru yang di didik pada Fakultas Ilmu Pendidikan dan Keguruan harus melalui dan lulus beberapa mata kuliah yang menjadi dasar dalam menjadi seorang guru, salah satunya mata kuliah belajar dan pembelajaran. Mata kuliah belajar dan pembelajaran merupakan mata kuliah wajib. Berdasarkan obsservasi pelaksanaan kuliah dilaksanakan dengan pembelajaran yang masih konvesional dengan bahan pembelajaran masih mengkonfilasi beberapa sumber yanga adan referensi yang digunakan masih terbitan lama sehingga ada beberapa materi yang kurang sesuai dengan keadaan hari ini. Kemudian hasil wawancara dengan mahasiswa menunjukkan banyak materi bahan ajar yang sulit di diaplikasi dalam pembelajaran sesungguhnya. Sehingga menyebabkan mahasiswa kurang berminat untuk belajar karena tidak tahu kegunaan dan susah mengaplikasi dalam kehidupan nyata di sekolah.

Berdasarkan masalah di atas, maka dirasa perlu untuk mengadakan penelitian Pengembangan Bahan Ajar Mata Kuliah Belajar Dan Pembelajaran Di Fakultas Keguruan dan Ilmu Pendidikan Di Universitas Batanghari Jambi. Dalam pengembangan perlu dikaji Bagaimanakah proses pembelajaran dan bahan ajar yang digunakan dalam mata kuliah belajar dan pembelajaran di FKIP Universitas Batanghari Jambi? Dan Bagaimanakah mengembangkan bahan ajar mata kuliah belajar dan pembelajaran di FKIP Batanghari Jambi?

Memahami pengembangan bahan ajar maka terlebih perlu memahami teori-teori 
tentang konsep pengembangan, Model Dick and Carey, Bahan ajar, Belajar dan pembelajaran

\section{Konsep Pengembangan}

Pengembangan dalam arti yang sederhana adalah suatu proses, cara pembuatan. Pengembangan adalah salah satu upaya pendidikan formal dan non formal yang dilaksanakan secara sadar, berencana, terarah, teratur dan bertanggung jawab dalam rangka memperkenalkan, menumbuhkan, membimbing dan mengembangkan suatu dasar kepribadian yang seimbang, utuh dan selaras, pengetahuan dan keterampilan sesuai dengan bakat, keinginan serta kemampuannya, sebagai bekal untuk selanjutnya atas prakarsa sendiri, menambah, meningkatkan dan mengembangkan dirinya, sesama, maupun lingkungannya kearah tercapainya martabat, mutu dan kemampuan manusiawi yang optimal dan pribadi yang mandiri. (Hamdani, 2011:172).

Dalam pengembangan ada beberapa hal yang harus diperhatikan sesuai dengan pendapat Richey and Klein (2007: XV): The systematic of design, development and evaluation processs with the aim of establishing anempirical basis for the creation of instructional and non instructional products and tools and new or enhanced models that gavern their development. Pernyataan tersebut ada beberapa point yang harus diperhatikan dalam pengembangan bahan ajar yaitu: (1) Penelitian desain pengembangan adalah merupakan suatu studi (yang meliputi proses perancangan, pengembangan, dan evaluasi) yang sistematis, (2) Tujuannya adalah untuk menciptakan suatu produk dan alat baik yang bersifat pembelajaran (instruksional) maupun non pembelajaran. Out put dari penelitian desain dan pengembangan dapat berbentuk produk maupun alat, (3) Produk dan alat yang dihasilkan tersebut dapat berupa hal baru maupun memperbaiki yang sudah ada.

Dari pendapat para ahlitersbut dapat dikatakan bahwa pengembangan instruksional merupakan cara yang sistematis yang dilakukan secara sadar dengan tahapan perancangan, pengembangan, evaluasi untuk menghasilkan produk, alat dan model pengembangan yang baru maupaun memperbaiki yang sudah ada. Pada pengembangan banyak model pengembangan salah satunya model Dick and Carey.

\section{Model Dick and Carey}

Model pembelajaran Dick and Carey telah lama digunakan untuk menciptakan program pembelajaran yang efektif, efisien dan menarik. Model yang kembangkan didasarkan penguasaan pendekatan sistem terhadap komponen-komponen dasar dari desain sistem pembelajaran. Pengembangan desain sistem pembelajaran ini tidak hanya diperoleh dari teori dan hasil penelitian, tetapi juga dari pengalaman praktis yang diperoleh dari lapangan. Implementasi model Dick and Carey memerlukan proses yang sistematis dan menyeluruh agar dapat digunakan secara optimal dan mengatasi masalah-masalah pembelajaran.

Langkah-langkah model pengembangan Dick and Carey terdiri dari sepuluh langkah dapat dilihat pada gambar 1:

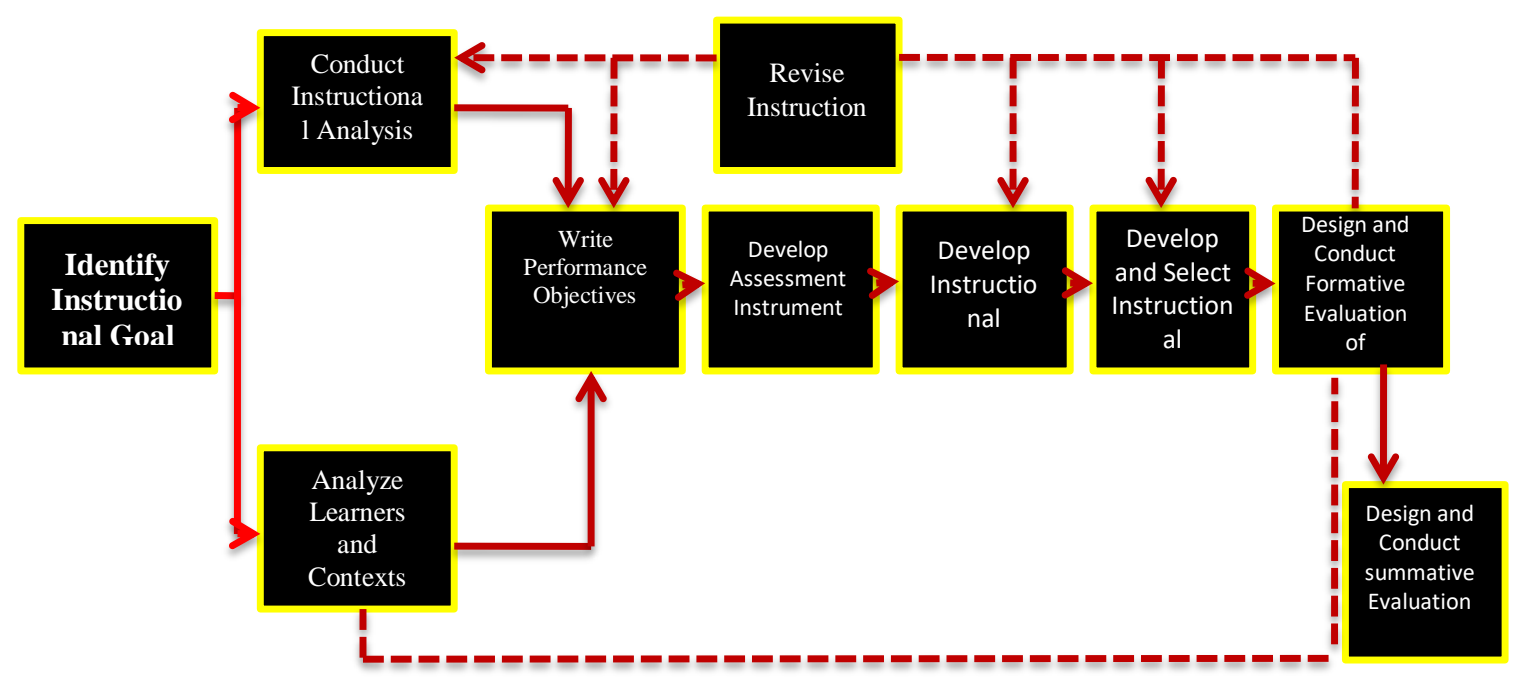

Gambar 1. Model Dick and Carey (Walter Dick, Lou Carey and James O Carey, 2005: 6) 
Dari gambar 1 dapat ddi deksripsikan sebagai berikut:

\section{1). Identifikasi Tujuan Pembelajaran (Identify Instructional Goal)}

Langkah ini adalah mengidentifikasi kemampuan atau kompetensi yang perlu dimiliki mahasiswa setelah menempuh pembelajaran atau disebut tujuan pembelajaran.“ Rumusan tujuan pembelajaran dapat dikembangkan dari tujuan yang terdapat dalam silabus, analisis kinerja, maupun dimulai dari proses analisis kebutuhan serta pengalamanpengalaman kesulitan belajar yang dihadapi mahasiswa (Walter Dick, Lou Carey and James O Carey, 2005: 6).

\section{2). Analisis Instruktional}

Setelah melakukan identifikasi tujuan pembelajaran, langkah selanjutnya adalah melakukan analisis instruktional, yaitu sebuah prosedur untuk mengetahui keterampilan dan pengetahuan yang relevan dan diperlukan mahasiswa untuk mencapai tujuan pembelajaran. Dalam melakukan analisis instruktional, beberapa langkah diperlukan untuk mengidentifikasi kompetensi, berupa keterampilan, pengetahuan, sikap, yang perlu dimiliki mahasiswa setelah mengikuti proses pembelajaran. Proses analisis instruktional dilakukan dengan mengunakan diagram yang mengambarkan keterkaitan dan hubungan seluruh keterampilan dan kemampuan yang dibutuhkan dalam mencapai tujuan dan kompetensi (Walter Dick, Lou Carey and James O Carey, 2005: 6).

\section{3). Analisis Karakteristik Mahasiswa dan Kontek}

Selain malakukan analisis tujuan pembelajaran yang perlu dilakukan dalam menerapkan model ini adalah analisis terhadap karakteristik mahasiswa dan konteks pembelajaran ini dapat dilakukan secara bersamaan. Analisis konteks meliputi kondisikondisi terkait dengan keterampilan yang dipelajari. Analisis terhadap karakteristik mahasiswa meliputi kemampuan aktual yang dimiliki mahasiswa, gaya belajar, dan sikap terhadap aktivitas belajar. Identifikasi ini menentukan strategi yang akan digunakan.

\section{4). Merumuskan Tujuan Instruktional Khusus}

Berdasarkan hasil analisis instruktional seorang perancang pembelajaran perlu kiranya mengembangkan tujuan pembelajaran khusus yang perlu dikuasai mahasiswa untuk mencapai tujuan pembelajaran yang bersifat umum. Dalam merumuskan tujuan pembelajaran khusus ada beberapa hal yang perlu mendapat perhatian, yaitu: (1) Menentukan pengetahuan dan keterampilan yang perlu dimiliki oleh mahasiswa setelah menempuh proses pembelajaran; (2) Kondisi yang diperlukan agar mahasiswa dapat melakukan unjuk kemampuan dari pengetahuan yang telah dipelajari; (3) indikator atau kreteria yang dapat digunakan untuk menentukan keberhasilan mahasiswa dalam menempuh proses pembelajaran.

\section{5). Mengembangkan Alat atau Instrumen Penilaian}

Berdasarkan tujuan atau kompetensi yang telah dirumuskan, langkah selanjutnya adalah mengembangkan alat atau instrumen penilaian yang mampu mengukur pencapaian hasil belajar mahasiswa."Hal ini dikenal dengan evaluasi hasil belajar (Walter Dick, Lou Carey and James O Carey, 2005: 6).

\section{6). Mengembangkan Strategi Pembelajaran}

Bentuk strategi yang digunakan dalam mengimplementasikan aktivitas pembelajaran yaitu: (1) aktivitas pra pembelajaran; (2) penyajian materi pembelajaran; dan (3) aktivitas pembelajaran tindak lanjut. Pemelihan strategi pembelajaran yang tepat perlu dilakukan dalam mendesain berbagai aktivitas pembelajaran seperti pembelajaran yang berlangsung di kelas, pembelajaran yang mengunakan jaringan komputer atau internet dan web (Walter Dick, Lou Carey and James O Carey, 2005: 7).

\section{7). Mengembangkan Bahan Ajar}

Pada tahap ini perancang pembelajaran dapat menerapkan strategi pembelajaran ke dalam bahan ajar yang digunakan yang dapat membawa informasi dan pesan dari sumber belajar mahasiswa. Bahan ajar yang digunakan dalam aktivitas pembelajaran dapat berupa buku teks, buku panduan, modul, program audio video, bahan ajar berbasis komputer, program multimedia dan bahan ajar yang digunakan pada sistem pendidikan jarak jauh (Walter Dick, Lou Carey and James O Carey, 2005: 7)

\section{8). Merancang dan Melaksanakan Evaluasi Formatif}

Evaluasi formatif dilakukan untuk mengumpulkan data yang terkait dengan kekuatan dan kelemahan program pembelajaran.Hasil dari evaluasi formatif dapat digunakan sebagai masukan untuk memperbaiki draf program. Ada tiga jenis evaluasi yan dapat diaplikasikan untuk mengembangkan produk pembelajaran, yaitu: (1) evaluasi satu-satu 
(oneto one); (2) evaluasi kelompok kecil (small group); dan (3) evaluasi lapangan.

\section{9). Melakukan Revisi}

Langkah akhir dalam proses desain sistem pembelajaran adalah melakukan revisi terhadap draf program pembelajaran. Data yang diperoleh dari evaluasi formatif dikumpulkan dan ditafsirkan untuk mengetahui kelemahankelemahan yang dimiliki program pembelajaran, yang tujuannya untuk memperbaiki dan meningkatkan kualitas program pembelajaran (Walter Dick, Lou Carey and James O Carey, 2005: 7).

\section{0). Merancang dan mengambangkan Evaluasi Sumatif}

Evaluasi sumatif dilakukan setelah program selesai dievaluasi secara formatif, dan direvisi sesuai dengan standar perancang.Evaluasi sumatif tidak melibatkan perancang program, tetapi melibatkan independen. Hal ini merupakan satu alasan untuk menyatakan bahwa evaluasi sumatif tidak tergolong kedalam proses desain sistem instruktional (Walter Dick, Lou Carey and James O Carey, 2005: 7)

Kesepuluh langkah model Dick and Care merupakan sebuah prosedur yang mengunakan pendekatan sistem dalam mendesain program pembelajaran. Setiap langkah mempunyai keterkaitan satu sama lain. Output yang dihasilkan dari suatu langkah akan digunakan sebagai infut langkah yang lain.

\section{Relevansi Model Pengembangan}

Pada penelitian pengembangan ini menggunakan model Dick and Carey. Model pengembangan Dick and Carey Relevansi dalam pengembangan bahan ajar pada mata kuliah belajar dan pembelajaran dengan alasan bahwa model Dick and Carey pada setiap langkah runtuh dan jelas, Analisis tugas yang tersusun secara terperinci dan tujuan pembelajaran instruksional khusus secara hirarki serta sistem dapat diandalkan karena dilakukan uji coba secara berulang-ulang. Disamping itu model pengembangan instruksional sangat sederhana dan mudah dimengerti, serta output model ini nantinya diharapkan mempunyai kekhasan

Model Dick and Carey dikembangkan didasarkan penguasaan pendekatan sistem terhadap komponen-komponen dasar. Implementasi model Dick and Carey memerlukan proses yang sistematis dan menyeluruh. Hal ini diperlukan untuk dapat menciptakan bahan ajar yang mampu digunakan secara optimal dan mengatasi masalah-masalah pembelajaran.

\section{Bahan ajar}

Menurut Abdul Majid (2007: 174) Bahan ajar adalah segala bentuk bahan yang digunakan untuk membantu guru/instruktur dalam melaksanakan kegiatan pembelajaran di kelas. Bahan yang dimaksud bisa berupa bahan tertulis maupun bahan ajar tidak tertulis. Komponen Bahan ajar atau materi pembelajaran (instructional materials) secara garis besar terdiri atas pengetahuan, keterampilan, dan sikap yang harus dipelajari siswa dalam rangka mencapai tujuan kompetensi yang telah ditentukan (Hamdani, 2011:120).

Jenis bahan ajar dikelompokkan menjadi empat kategori yaitu bahan ajar pandang (visual) terdiri atas bahan cetak dan non cetak, bahan ajar dengan (audio), bahan ajar pandang dengar (audio visual), bahan ajar multimedia interaktif (interactive teaching material) (Amri \& Ahmadi (2010). Berdasarkan teknologi yang digunakan Depdiknas, 2008) mengelompokkan bahan ajar menjadi empat kategori, yaitu bahan ajar cetak (printed), bahan ajar dengar (audio), bahan ajar pandang dengar (audio visual), bahan ajar multimedia interaktif (interactive teaching material) dan bahan ajar berbasis web (web based learning materials).

Bahan ajar cetak mampu menyajikan materi yang mudah dipahami oleh penggunanya. Oleh sebab itu, seorang desainer, dosen, instrukstur, dan guru harus mampu membuat bahan ajar cetak yang sesuai dengan kebutuhan si pembelajar. Ada banyak sekali macam dari bahan ajar cetak menurut (Amri \& Ahmadi, 2010) beberapa diantaranya adalah hand out, buku, modul, lembar kerja siswa, brosur, leaflet, wallchart, foto/gambar.

Dari pendapat ahli di atas di simpulkan bahwa bahan ajar adalah segala bentuk bahan cetak atau noncetak, audio, aodio visual, multimedia interaktif.yang digunakan untuk membantu pelaksaaan pembelajaran untuk mencapai tujuan yang ditetapkan dengan memiliki aspek pengetahuan, ketrampilan dan sikap .

\section{Belajar dan Pembelajaran}

Menurut Burton (Hosnan, 2014) Belajar adalah perubahan tingkah laku pada diri individu berkat adanya interaksi antara individu dengan individu ataupun antara individu dengan lingkungannya sehingga dapat berinteraksi 
dengan lingkungannya. Berati belajar merupakan perubahan tingkah laku dengan berintekasi dengan lingkungannya. Kemudian Gagne (1992: 3) pembelajaran sebagai "Instruction is a set of events that affect learning is facilitated" Pembelajaran adalah serangkaian aktivitas yang disengaja diciptakan dengan maksud memudahkan terjadinya proses belajar. Menurut Reigeluth (2009:6)“ Instructional as anything that is done purposely to facilitate learning. Pembelajaran yang dimaknai sebagai usaha yang bertujuan membantu untuk memfasilitasi untuk belajar. Menurut Miarso (2004:545), "pembelajaran adalah suatu usaha yang disengaja, bertujuan, dan terkendali agar orang lain belajar atau terjadi perubahan yang relative menetap pada diri orang lain".

Dari pendapat ahli disimpulkan bahwa pembelajaran merupakan suatu usaha memfasilitasi belajar dan dilakukan dengan sengaja untuk terjadi perubahan tingkah laku yang relativ menetap.

\section{METODE PENELITIAN}

Metode yang diterapkan adalah metode penelitian dan pengembangan $(R \& D)$ yang akan menghasilkan suatu produk atau menguji keefektifan produk tertentu. Dalam pengembangan bahan ajar ini dilakukan melalui langkah-langkah 1) studi pendahuluan, 2) perencanaan pengembangan, 3) validasi, evaluasi dan revisi, 4) dan implementasi. Bahan ajar yang dikembangkan agar berkualitas maka dilakukan Validasi dan evaluasi formatif yang ditelaah oleh : (1) one to one expert, yakni ahli materi, ahli desain intruksional dan ahli multimedia, (2) one to one learner, yaitu uji coba perorangan yang dilakukan terhadap subjek pengguna yaitu mahasiswa sebagai pemakai teridir dari tiga orang mahasiswa yang memiliki kemampuan rendah, sedang dan tinggi, (3) small group, yaitu ujicoba kelompok kecil tentang kesesuaian prinsip-prinsip pembelajaran dengan pripsip penggunaan yang diujikan kepada 9 orang mahasiswa terdiri dari 3 kemampuan rendah, 3 kemampuan sedang dan 3 kemampuan tinggi, (4) field trial, yaitu ujicoba lapangan dilakukan pada 20 orang mahasiswa.

\section{HASIL DAN PEMBAHASAN}

\section{Analisis Kebutuhan dan Perumusan Tujuan}

Berdasarkan hasil dengan doenn, menujukkan bahwa saat ini dosen dalam mengajar masih menggunakan referensi belajar dan pembelajaran yang belum sesuai dengan silabus. Buku belajar dan pembelajaran belum di susun menjadi satu buku namaun masih terpisah-pisah buku yang satu dengan yang lain sehingga mahasiswa susah dalam mencari referensi. Selain itu, buku yang dgunakan harus di update dengan keadaaan yang terjadi saat ini seperti strategi pembelajaran yang terus berkembang sesuai tututan zaman. kemudian observasi langsung, terbukti mahasiswa sangat menginginkan proses pembelajaran menggunakan bahan ajar yang jelas sesuai dengan silabus dan perkembangan zaman saat ini. Dari hasil wawancara peneliti dengan teman sejawat atau dosen, maka sistem pembelajaran yang digunakan masih secara konvensional yaitu menggunakan metode ceramah, dan menggunakan berbagai macam media sebagai sarana pendukung untuk menjelaskan materi perkuliahan, sehingga perlu inovasi dari segi pembelajaran.

Secara umum, setelah mempelajari mata kuliah Belajar Pembelajaran mahasiswa diharapkan dapat menerapkan dalam dunia pendidikan

\section{Analisis instruksional}

Analisis intruksioanl merupakan proses menjabarkan perilaku umum menjadi perilaku khusus yang tersusun secara logis dan matematis.Peta kompetensi menggunakan kata kerja operasional dengan: Mendekripsikan hakikat belajar dan Jenis-jenis belajar, Menjelaskan prinsip-prinsip dan faktor-faktor yang mempengaruhi belajar, Menjelaskan Motivasi belajar, Menjelaskan teori-teori belajar, Menjelaskan hakikat pembelajaran, Menjelaskan komponen pembelajaran, Menjelaskan pendekatan pembelajaran, Menjelaskan Modelmodel pembelajaran,

\section{Mengidentifikasi Perilaku dan Karakteristik Awal}

Kelompok yang menjadi sasaran dalam penelitian ini adalah mahasiswa program studi pendidikan matematika yang sedang menempuh mata kuliah belajar dan pembelajaran pada semester empat (IV) Karakteristik mahasiswa yang akan menggunakan bahan yang memiliki latar belakang pendidikan yang heterogen, seperti dari SMA, SMK dan MA. Mahasiswa tersebut memiliki motivasi dan kemauan yang tinggi dalam mempelajari belajar dan pembelajaran. 


\section{Merumus Tujuan Instruksional Khusus}

Dari tujuan instruksional umum di atas, maka dapat dijabarkan tujuan instruksional khusus adalah Mahasiwwa dapat : (a) Mendekripsikan hakikat belajar dan Jenis-jenis belajar, (b) Menjelaskan prinsip-prinsip dan faktor-faktor yang mempengaruhi belajar, (c) Menjelaskan Motivasi belajar, (d) Menjelaskan teori-teori belajar, (e) Menjelaskan Hakikat Pembelajaran, (f) Mahasiswa dapat menjelaskan komponen pembelajaran, (g) Menjelaskan pendekatan pembelajaran (h) Menjelaskan Model-model pembelajaran.

\section{Alat Penilaian}

Penilaian terdiri dari ujian tengah semester, ujian semester, partsipasi dan uji kompetensi

\section{Menyusun Strategi Pembelajaran}

Pembuatan strategi pembelajaran dilakukan berdasarkan urutan kegiatan pembelajaran yaitu tahap pendahuluan, tahap penyajian dan tahap penutup. Kemudian komponen berikutnya terdiri dari garis besar materi, metode, media dan alat dan waktu belajar

\section{Mengembangkan Bahan Pembelajaran}

Materi pembelajaran mata kuliah Belajar dan Pembelajaran terdiri dari materi pembelajaran yang telah dibukukan sebanyak delapan bab. Bahan ajar yang sudah dikembangkan perlu dilihat kelayakannya. Adapun hasil kelayakan yang terdiri dari validasi dan evaluasi formatif adalah sebagai berikut:

\section{Uji Ahli (one to one expert)}

1. ahli desain pembelajaran

Hasil validasi ahli desain pembelajaran berdasarkan indikator yang dituangkan menggunakan grafik 1 :

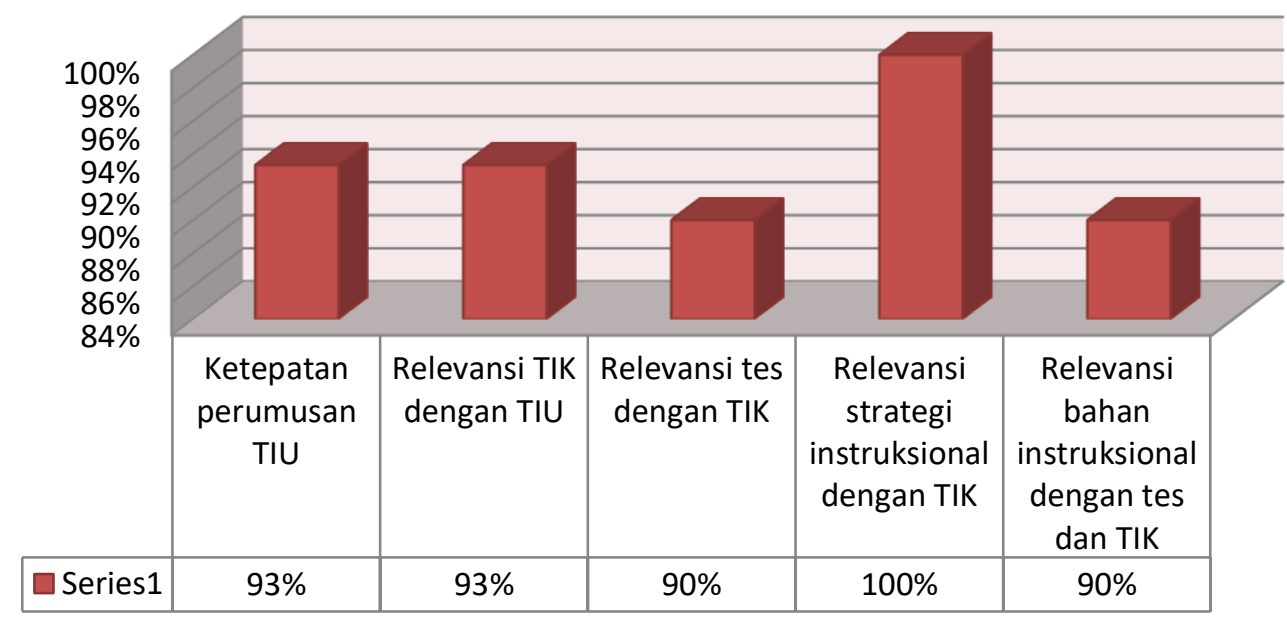

2. Ahli Materi

Grafik 1. Hasil Validasi Ahli Desain Pembelajaran ke-1

Hasil validasi oleh ahli materi berdasarkan indikator terhadap bahan ajar

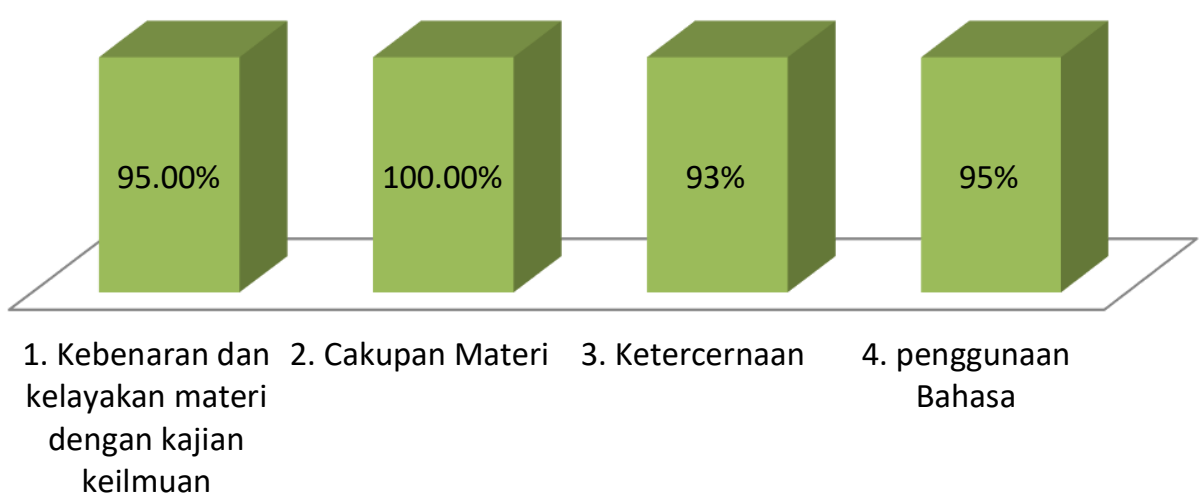

Grafik 2. Grafik Hasil Validasi Ahli materi 
3. Ahli Media

Adapun hasil validasi oleh ahli media

pembelajaran dituangkan dalam bentuk terhadap draf bahan pembejaran belajar dan

Grafik 3.

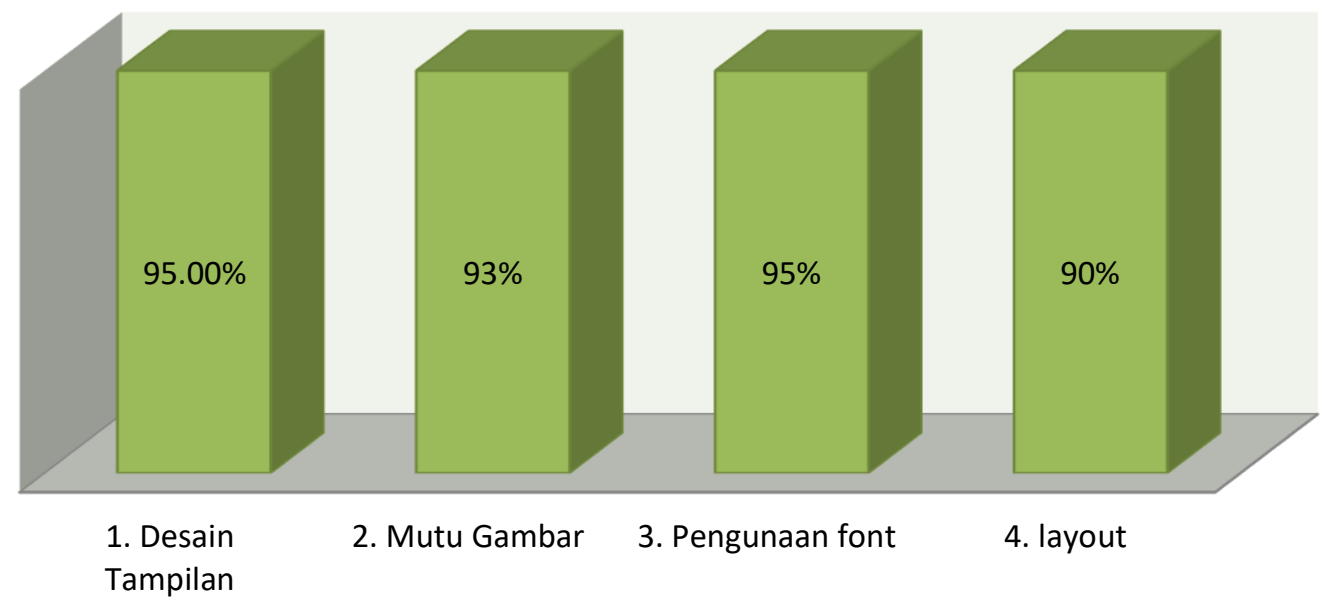

Grafik 3 hasil validasi ahli media

4. Revisi dan Saran dari Ahli

Ahli desain menyarankan agar setiap materi yang disajikan dari setiap bab dilengkapi dan didukung dengan foto dan desain sebagai penjelas materi bahan pembelajaran. kemudian tes yang dilakukan sesuai dengan tujuan pada sub materi yang disajikan. Semua sudah di perbaiki dan direkomendasikan untuk uji one to one learner.

Tanggapan ahli materi secara keseluruhan termasuk dalam kategori sangat baik. Namun saran yaitu penggunaan bahasa diharapkan lebih komunikatif agar mudah untuk memahaminya dan tambahkan pengayaan dengan menggunakan contohcontoh yang lebih kongkrit. Saran ahli materi telah di perbaiki danmerekomendasikan untuk melakukan uji one to one learner

Ahli media menyarankan pertama agar pengunaan gambar, foto dalam bahan pembelajaran di sajikan dengan proposional sesuai dengan gambar aslinya dan tidak melebar. Kedua, pengetikan bahan pembelajaran hendaknya menggunakan program aplikasi khusus untuk percetakan buku yaitu abode design. Ketiga, jenis ukuran kertas bahan ajar yang digunakan disarankan menggunakan ukuran kertas B5 yang hampir sama dengan ukuran kertas buku yang digunakan oleh beberapa penerbit buku. Saran dari ahli media telah diperbaiki ahli merekomendasikan untuk melakukan uji $\mathrm{p}$ one to one leaner.

\section{Uji coba perorangan (one to one leaner)}

Tanggapan pada uji one to one leaner yaitu ada beberapa kata yang susah dipahami karena kata tersebut merupakan bahasa ilmiah. Kata-kata yang susah di pahami tersebut sudah diperbaiki dengan berdiskusi dengan pengguna dan telah diganti dengan bahasa yang mudah dipahami. Selain itu, ada kata-kata yang meragukan dan sudah diperbaiki sesuai dengan hasil diskusi dengan mahasiswa uji one to one leaner

\section{Uji coba kelompok kecil (small group)}

Tanggapan dari uji small group yang diambil melalui angket secara kualitatif, sudah tidak ada masalah yang mendasar, namun ada sedikit masalah sikap terhadap materi yang disukai dan tidak di sukai, namun hal tersebut tetap harus dipelajari.

\section{Uji coba kelompok lapangan (field trial)}

Tanggapan subjek pada uji coba kelompok lapangan adalah pelaksanaan pembelajaran lancar dan menyenangkan, dengan bahan ajar yang mudah dipahami dan sesuai dengan kebutuhan subjek. Selain itu ukuran dengan B5 membuat tampilan bahan ajar lebih menarik dan mudah membawanya.

\section{Pembahasan \\ Peran Bahan Pembelajaran belajar dan pembelajaran}

Para pelaksanaan pembelajaran akan efektif apabila diawali dengan rancangan pembelajaran yang efektif. Pandangan ini 
didasari pendapat "Effective teaching begins with effective planning of instruction" (Jones dan Davis, 2011: 101). Pendapat ini menegaskan pentingan rancangan dalam pembelajaran termasuk merancang bahan ajar. Bahan ajar betujuan memudahkan mahasiwa untuk mempelajari materi-materi atau informasi yang disampaikan agar dapat dipelajari secara efektif dan efisien sehingga mencapai tujuan instruksional.

Pentingnya bahan ajar menuntut pendidik untuk berinovasi. Namu demikian para dosen belum menggunakan buku belajar dan pembelajaran yang sesuai dengan keadaan daerah. Buku yang di gunakan masih dalam bentuk buku belajar dan pembelajaran secara umum sehingga mahasiswa dalam membuat tugas masih kebinggungan mencari sumbersumber lain karena belum tersusun sesuai dengan silabus yang digunakan. Hasil ini menunjukan bahwa perlu dikaji kembali masalah bahan ajar yang sesuai dengan kebutuhan dan kondisi yanga ada. Untuk mendapatkan hasil yang makasimal maka diperlukan model pengembangan yang sesuai, Salah satunya Dick and Carey. Model Dick and Carey memiliki langkah runtuh dan jelas, Analisis tugas yang tersusun secara terperinci dan tujuan pembelajaran instruksional khusus secara hirarki serta sistem dapat diandalkan karena dilakukan uji coba secara berulang-ulang. Disamping itu model Dick and Carey sangat sederhana dan mudah dimengerti, serta output model ini nantinya diharapkan mempunyai kekhasan.

Pada analisis kebutuhan menunjukkan bahwa bahan aja belajar dan pembelajaran di butuh dan perlu dikaji secara rinci. Oleh sebab itu penyusunan harus berpedoman kepada tujuan instruksional umum di tetapkan. Dengan demikian akan terlihat materi yang harus ada untuk mencapai tujuan tersebut. Selain itu, perlu juga mengkaji strategi penggunaan bahan ajar yang dilakukan. Semua sudah dilakukan dan telah dievaluasi melalui para ahli dan uji coba perorangan, kelompok kecil dan kelompok lapangan dan mendapat hasil yang sangat memuaskan. .

\section{Prosedural pengembangan Bahan ajar belajar dan pembelajaran matematika}

Prosedur mengembangan bahan ajar belajar dan pembelajaran berpedoman pada desain sistem instruksional menggunakan model Dick and Carey. Model Dick and Carey. Merupakan salah satu model pengembangan yang populer pada dunia pendidikan karena dengan langkah yang runtut dan jelas serta mudah dipahami. model Dick and Carey dimulai dari menganalis kebutuhan dana menetapkan tujuan intruksional umum. Untuk mencapai tujuan instruksional umum dibutuhkan analisis instruksional untuk menentukan batasan kompentesi yang harus dimiliki oleh mahasiswa, mana yang sudah dikuasai dan yang belum. Langkah selanjutnya adalah menganalisi karakteristik dan kemampuan awal mahasiswa sehingga bisa menentukan dari mana materi dimulai dan strategi yang digunakan. Dan dilanjutkan dengan penentuan tujuan istruksional khusus untuk mencapai tujuan umum dan dalam mencapai tujuan tersebut tentu dibutuh tes acuan patokan yang menjadi acuan yang harus dipenuhi sebagai pedoman dalam menyusun materi. Model dick and Carey merupakan model dan pendekatan sistem, tentu ada pengembangan strategi pembelajaran yang akan dilakukan, dengan demikian akan mudah dalam mengembangkan bahan pembelajaran. setelah bahan ajar di kembangan di lanjutkan dengan evaluasi para ahli materi, desain, media untuk melihat kelayakan bahan ajar yang di buat. Selain itu untuk setiap orang memiliki kemampuan yang berbeda dalam menganalis atau memahami suatu materi. Oleh sebab itu di lakukan uji coba dari perseorangan, kelompok kecil dan kelompok besar agar hasil bahan ajar beberapa sesuai dengan kebutuhan dan karakterik pengguna.

\section{Keterbatasan Penelitian}

Model Disck and Carey memiliki sepuluh langkah yang harus dilalui untuk mendapatkan hasil yang baik. Dari sempuluh langkah tersebut, penelitian ini hanya sampai pada langkah kesembilan sedangkan lanagkah kesepuluh yaitu evaluasi sumatif tidak dilakukan. Hal ini disebabkan, pada langkah ke sepuluh yaitu melaksanakan evaluasi sumatif membutuhkan waktu yang cukup lama, yaitu sekitas 6 bulan sampai satu tahun.

Selain itu pertimbangan dalam penelitian pengembangan diperlukan yang matang, karena membutuhkan waktu yang lama, mulai dari persiapan, pelaksanaan, pengembangan produk, validasi sampai proses uji coba. Setiap langkah tersebut membutuhkan bahan, tenaga dan bantuan orang lain sehingga ada memerlukan biaya yang cukup. Kemudian Penelitian dilakukan hanya terbatas untuk mata kuliah belajar dan pembelajaran yang memiliki karakteristik dan kemampuan awal yang sesuai 
dengan penelitian pendahuluan sehingga perlu dikaji untuk peneliti selanjutnya.

\section{SIMPULAN}

1. Pelaksanaan pembelajaran mata kuliah belajar dan embelajaran yang sebelumnya masih menggunakan buku-buku yang masih bersifat umum sehingga membutuhkan banyak buku lain untuk melengkapi materi yang akan dipelajari. Selain ini proses pembelajaran masih bersifat konvensional yakni hanya menggunakan metode ceramah yang harus mengusai materi yang disampaikan sehingga mahasiswa menjadi penuruh dan tidak kritis dalam pembelajaran.

2. Prosedural dalam merancang dan mengembangkan bahan ajar belajar dan pembelajaran menggunakan model Dick and Carey dilakukan untuk mendesain bahan ajar dalam bentuk buku. Selanjutnya Melakukan evaluasi formatif. Hasil evaluasi formatif dari dari beberapa validasi ahli/pakar menyimpulkan bahwa produk pengembangan bahan ajar belajar dan pembelajaran telah dilakukan sesuai dengan metode, prosedur, prinsip, dan berpedoman pada model pengembangan, penelitian pendahuluan, pengembangan produk dan evaluasi formatif. Tim ahli/pakar merekomendasikan bahwa model yang dikembangkan layak digunakan. Dan di lanjutkan dengan uji one to one, small group, dan field trial dan hasil semua uji coba mendapat hasil yang baik sehingga bahan ajar belajar dan pembelajaran layak digunakan.

\section{DAFTAR PUSTAKA}

Abdul Majid 2007, Perencanaan Pembelajaran Mengembangkan Standar Kompetensi Guru, Bandung: PT. Remaja Rosdakarya Offset
Amri \&Ahmadi. 2010. Konstruksi Pengembangan Pembelajaran: Pengaruhnya Terhadap Mekanisme dan Praktik Kurikulum. Jakarta: Prestasi Pustakaraya

Charles. M.Reigeluth, Alison A. CarrChellman.2009, Instructional Design Theories and Model Volume lll: Building a Common Knowledge Base. New York: Roudledge

Hamdani 2011, Strategi Belajar Mengajar, Bandung: CV. Pustaka Setia
Hamdani. 2011, Strategi Belajar Mengajar,Bandung: CV. Pustaka Setia

Hosnan. 2014. Pendekatan Saintifik dan Kontekstual dalam Pembelajaran Abad 21. Jakarta: Ghalia Indonesia.

Paula Jones dan Rita Davis. 2011, Instructional Design Methods Integrating Instructional Technology, New York, Hershey: Information Science Reference, 2011

Richey, C. Rita, Klein, D. James.2007. Design and Development Research. New Jersey: Lawrence Lrlbaum Associates. 2007

Robert M Gagne, Lislie Briggs and Walter W Wager. 1992. Principles of Instructional Design. New York: Harcourt Brace Jovanorich College Publisher

Walter Dick, Lou Carey and James O Carey. 2009, The Systematic Design of Instruction, New: Jersey: Person.

Walter Dick, Lou Carey, and James O Cerey 2005 , The Sistematic Design of Insruction: Sixth Edition, New York: Pearson.

Yusufhadi Miarso. 2004, Menyemai Benih Teknologi Pendidikan, Jakarta: Kencana 